\title{
PENGUATAN SINYAL GLOBAL SYSTEM FOR MOBILE COMMUNICATION (GSM) MENGGUNAKAN ANTENA YAGI 14 ELEMEN
}

\author{
Oleh : \\ Firdaus, Ratna Dewi, Rikki Vitria, Lifwarda \\ Jurusan Teknik Elektro Politeknik Negeri Padang \\ firdaus_pnp@yahoo.com,ratnadewi.okt@gmail.com
}

\begin{abstract}
The hand phone provides an easy to communicate in domestic calls or international calls. The radiation pattern of yagi antenna leads to one direction. Therefore, this antenna is selected for signal amplifier in global system of mobile communication. The design of 14 element yagi antenna which applied for signal amplification in the cell phones was conducted in this study. The design was done manually without computer software. The antenna was created using an aluminum pipe in 3/8 inch diameter for element and an aluminum beam for boom. The result showed that the operating frequency between the designed antenna and manufactured antenna are the same i.e. $947 \mathrm{MHz}$. The bandwidth of yagi antenna is $9 \mathrm{MHz}$. Moreover, the antenna gain which measured in folded antenna transmitter and BTS transmitter are $16 \mathrm{~dB}$ and $12 \mathrm{~dB}$ respectively. That result is caused differences in distance at the measurement time. Utilization of yagi antenna has succeeded to increase signal amplification in hand phone.
\end{abstract}

Keyword: handphone, yagi antenna, global system for mobilecommunication (GSM), radiation pattern, bandwidth, gain

\section{PENDAHULUAN}

Pada saat ini perkembangan telekomunikasi berperan penting untuk memperlancar komunikasi pada kehidupan masyarakat, pemerintah, dan usaha-usaha pembangunan. Telekomunikasi telah dinikmati oleh masyarakat melalui televisi, handphone, radio dan lain sebagainya. Sehingga alatalat telekomunikasi tersebut sudah bisa dikatakan sebagai barang primer bagi masyarakat luas.

Perkembangan handphone merupakan contoh komunikasi yang telah memberikan pengaruh besar dalam pola hidup masyarakat. Handphone memberikan kemudahan untuk berkomunikasi dalam negeri maupun luar negeri. Namun untuk mendapatkan sinyal yang kuat atau berkualitas pada daerah-daerah tertentu terutama pada daerah yang memiliki jarak cukup jauh dari Base Transceiver System (BTS) memerlukan tambahan peralatan untuk menangkap kualitas sinyal yang baik. Untuk itu diperlukan antena yang radiasinya mampu menangkap sinyal pada daerah yang jaraknya jauh dari BTS [2].

Antena merupakan suatu struktur peralatan yang terdiri dari elemen logam yang digunakan untuk memancarkan atau menerima gelombang elektromaknetik yang ditransmisikan melalui udara bebas dan kemudian dikonversikan kembali kebentuk gelombang awal yaitu gelombang listrik. Proses pengonversian tersebut terjadi 
pada bagian antena. Salah satu antena yang memiliki pancaran radiasi yang mengarah adalah antena deret atau lebih dikenal sebagai antena yagi [4].

Antena yagi adalah antena yang di desain mempunyai banyak elemen yang dipasang secara deret. Antena jenis ini mempunyai pola pancaran yang mengarah ke satu tujuan (terarah).

Antena yagi memiliki elemen reflecktor, elemen driven dan elemen director, dimana fungsi elemen reflecktor sebagai pemantul gelombang sinyal agar dapat diterima dengan baik oleh elemen driven, elemen driven sebagai elemen yang dicatu dan elemen director berfungsi sebagai pengarah pada antena yagi untuk mendapatkan fokus pancaran sinyal.

Penambahan elemen reflector tidak memberikan peningkatan kemampuan antena sedangkan penambahan elemen director dapat meningkatkan gain dan direktifitas antena. Gain antena yagi dipengaruhi oleh jumlah elemen, antena yagi 12 elemen memiliki gain sebesar $14 \mathrm{~dB}^{\mathrm{i}}$ dan antena yagi 14 elemen memiliki gain sebesar $16 \mathrm{~dB}$.

Gain antena Global System For Mobilecommunication (GSM) bermacam-macam, Untuk GSM yang dipasang di semi-urban biasanya berkisar antara 15-18 $\mathrm{dB}^{\mathrm{ii}}$. Semakin besar diameter antena, semakin besar gain antena tersebut.

Adapun tujuan yang ingin dicapai dalam penelitian ini adalah:

1. Mendesain antena yagi sebagai penguat sinyal GSM pada handpone.

2. Untuk memahami fungsi elemenelemen pada antena yagi menurut jumlah elemen.

3. Mengetahui dan memahami sistem kerja penguat sinyal GSM dengan menggunakan antena yagi.

4. Sebagai bahan praktek di labor telekomunikasi.
Berdasarkan latar belakang diatas, maka penulis merumuskan permasalahan perancangan antena yagi 14 elemen yang digunakan sebagai media penerima sinyal dari Base Transceiver Station (BTS) untuk menguatkan sinyal pada handphone. Frekuensi handphone yang akan dikuatkan adalah frekuensi downlink GSM900 (935 MHz-960MHz).

\section{METODOLOGI}

\section{Antena Yagi-Uda}

Sejak ditemukan oleh S. Uda dan H. Yagi di universitas Tohoku pada tahun 1926, antena Yagi yang lebih tepat disebut antena Yagi - Uda banyak dibahas secara percobaan dan teori. Antena ini banyak sekali digunakan pada komunikasi radio amatir, dan kemudian sebagai antena penerima televisi, karena kemampuan kerjanya yang prima dan toleransinya terhadap variasi serta kesalahan konstruksi bila kinerja optimum bukan suatu tuntutan. Antena Yagi - Uda merupakan antena susun parasitik dari antena dipole. Antena ini umumnya terdiri dari sebuah reflektor, sebuah driven, dan beberapa direktor. Hal ini bermuara pada berbagai bentuk elemen antena Yagi - Uda seperti yang dapat dilihat di pasaran. Pada Gambar 1 memperlihatkan dimensi serta kontruksi dari antena yagi [4].

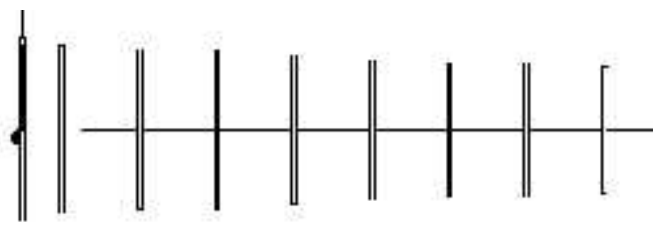

Gambar 1. Dimensi dan kontruksi antena Yagi-Uda

Antena Yagi-Uda yang termasuk dalam jenis antena - antena kanal gelombang berjalan, dalam bentuk bakunya terdiri dari sejumlah antena kawat dipole yang diletakkan sejajar 
dalam suatu bidang. Satu diantaranya merupakan dipole aktif, sedangkan yang lainnya adalah pasif. Satu dari dipole pasif ini berada dibelakang dipole aktif dan berfungsi sebagai pemantul, dipole pasif lainnya terletak di depan dipole aktif sebagai pengarah. Dalam konfigurasi ini arah depan merupakan arah pancaran antena. Diketahui dari teori - teori dipole gandeng bahwa dipole pasif akan berfungsi sebagai pemantul bila tahanan reaktifnya adalah induktif. Karena itu panjang pemantul lebih besar dari setengah panjang gelombang. Dipole pasif akan berlaku sebagai pengarah kalau tahanannya kapasitif, karena itu panjangnya kurang dari setengah panjang gelombang. Biasanya satu dipole cukup sebagai pemantul karena pemantul tambahan tidak banyak pengaruhnya terhadap pola pancaran antena. Sebaliknya karena arah pancar antena sesuai dengan kedudukan pengarah, eksitasi intensif secara seri yang membentuk kanal gelombang berjalan ditunjang oleh jumlah pengarah, sehingga jumlah pengarahnya antara 2 hingga 12 merupakan hal yang umum.

Sebuah elemen dalam sebuah antena susun mempunyai sebuah radiator yang memiliki panjang $1 / 2 \lambda$. Elemen array tersebut tidak selalu memiliki panjang $1 / 2 \lambda$ karena beberapa tipe dari array memiliki panjang yang disesuaikan / diinginkan yang menunjukkan elemen tersebut memiliki reaktansi kapasitif atau reaktansi induktif.

Elemen driven adalah suatu elemen yang menyediakan daya dari pemancar, biasanya melalui saluran transmisi. Sebuah elemen parasit adalah elemen yang memperoleh daya secara sendirinya melalui penggandengan dengan elemen lain pada array dikarenakan jarak antar elemen yang berdekatan antara elemen. Elemen driven mempunyai panjang $1 / 2 \lambda$. Sehingga rumus untuk menghitung total panjang elemen driven Yagi ditunjukkan pada Persamaan 1 sebagai berikut [3] :

$$
\mathrm{L}=0.5 \times \mathrm{K} \times \lambda
$$

Dimana:

$\mathrm{L}=$ Panjang Driven Element

$\mathrm{K}=$ Velocity Factor $($ pada logam 0.95 )

$\lambda=$ Panjang gelombang $(\mathrm{m})$

Sebuah elemen parasit pada Gambar 2 disebut sebagai pengarah / direktor ketika pengarah tersebut menghasilkan pola pancar maksimum di sepanjang garis perpendicular dari driven ke elemen parasit [3].

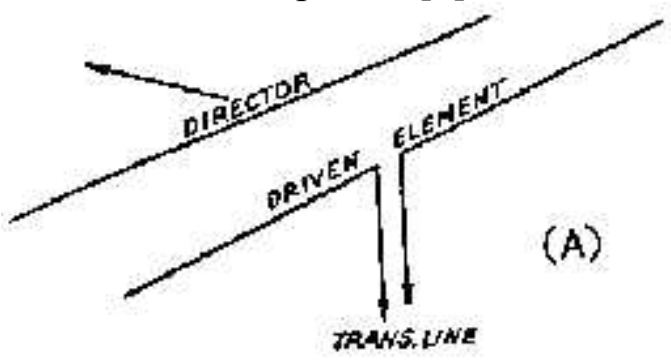

Gambar 2. Elemen direktor

Ketika radiasi maksimumnya berlawanan arah dengan pengarah / direktor dari elemen parasit melalui driven elemen seperti pada Gambar 3 maka elemen parasit itu dinamakan reflektor [3].

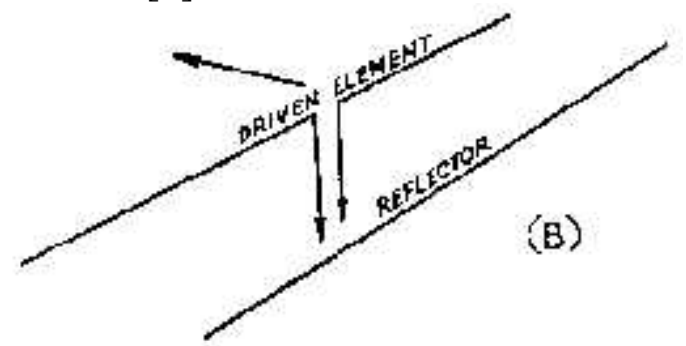

Gambar 3. Elemen reflektor

\section{Parameter Dasar Antena}

Parameter dasar antena digunakan untuk menguji atau mengukur performa antena yang akan digunakan. Berikut penjelasan beberapa parameter antena yang sering digunakan yaitu gain antena, pola radiasi antena, bandwith antena dan VSWR antena.

\section{Gain Antena}


Gain antena adalah perbandingan daya pancar suatu antena terhadap daya pancar antena referensi atau pertambahan daya diradiasikan pada arah tertentu. Dari antena yang dibandingkan ada daya yang diradiasikan pada arah yang sama oleh antena referensi.

Gain dapat dihitung dengan membandingkan kerapatan daya maksimum antena yang diukur (Antenna Under Test) dengan antena referensi yang diketahui gainnya. Berikut ini perhitungan gain [2] :

Gain (kali) $=\underline{\text { Pmax }(\text { antena yang diukur) } . . . . . ~}$ (2)

$$
\text { Pmin (antena referensi) }
$$

atau:

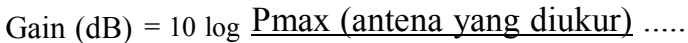
(3)

Pmin (antena referensi)

Error! Reference source not found. Atau dengan persamaan berikut ini [2]:

$G(\mathrm{~dB})=\mathrm{P} 1(\mathrm{dBw})-\mathrm{P} 2(\mathrm{dBw})$

(4)

$G(\mathrm{~dB})=\left(\frac{\text { Vawena yang aiveñum }}{\text { Vamena rejerensi }}\right)^{2} \quad \ldots$

\section{Polaradiasi Antena}

Pola radiasi antena didefenisikan sebagai gambaran kekuatan pancaran atau penerimaan sinyal suatu antena dalam fungsi sudut ${ }^{\text {iii }}$. Pola radiasi antena menjelaskan bagaimana antena meradiasikan energi ke ruang bebas atau bagaimana antena menerima energi. Gambar 4 menunjukkan pola radiasi antena dalam dua dimensi dan tiga dimensi [7].

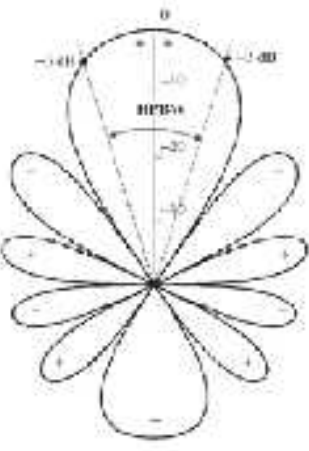

Dua dimensi

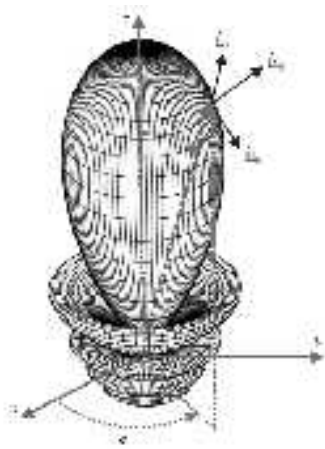

Tiga dimensi

Gambar 4. Dimensi Polaradiasi Antena

\section{Polarisasi Antena}

Polarisasi antena merupakan orientasi perambatan radiasi gelombang elektromagnetik yang dipancarkan oleh suatu antena di mana arah elemen antena terhadap permukaan bumi sebagai referensi arah. Dalam jaringan wireless, polarisasi dipilih dan digunakan untuk mengoptimalkan penerimaan sinyal yang diinginkan dan mengurangi derau dan interferensi dari sinyal yang tidak diinginkan. Gambar 5 menunjukkan polarisasi antena. Ada empat macam polarisasi antena yaitu polarisasi vertikal, polarisasi horizontal, polarisasi circular, dan polarisasi cross.

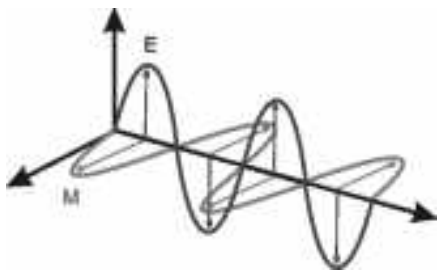

Gambar 5. Polarisasi Antena

\section{Bandwidth Antena}


Bandwidth suatu antena didefenisikan sebagai jangkauan frekuensi yang berada dalam performa antena tersebut, dengan berhubungan dengan beberapa sifat yang sesuai dengan standar yang telah ada ${ }^{\text {iv }}$.

Adapun bandwidth dapat dinyatakan pada Persamaan 6 [5]:

\section{Error! Reference source not found.}

Keterangan :

$f 2=$ frekuensi tertinggi

$f 1=$ frekuensi terendah

$f \mathrm{c}=$ frekuensi tengah

\section{Voltage Standing Wave Ratio (VSWR)}

VSWR adalah perbandingan antara amplitudo gelombang berdiri (standing wave) maksimum (|V|max) dengan minimum $(|V|$ min $)$. Pada saluran transmisi ada dua komponen gelombang tegangan, yaitu tegangan yang dikirimkan $(\mathrm{VO}+)$ dan tegangan yang direfleksikan ( $\mathrm{VO}-)$. Perbandingan antara tegangan yang direfleksikan dengan yang dikirimkan disebut sebagai koefisien refleksi tegangan $(г)$, dimana cara menentukan koefisien refleksi dengan persamaan 7 sebagai berikut [8] :

\section{Error! Reference source not found.}

Keterangan :

$\Gamma \quad=$ Koefisien refleksi

$\mathrm{V}_{0^{-}}=$Tegangan yang dikirim

$\mathrm{V}_{0}+=$ Tegangan yang direfleksikan

$Z_{L}=$ Impedansi beban (load)

$Z_{0}=$ Impedansi saluran lossless

Koefisien refleksi tegangan (г) memiliki nilai kompleks, yang merepresentasikan besarnya magnitudo dan fasa dari refleksi. Untuk beberapa kasus yang sederhana, ketika bagian imajiner dari adalah nol, maka :

a. $\Gamma=-1$ : refleksi negatif maksimum, ketika saluran terhubung singkat b. $\Gamma=0$ : tidak ada refleksi, ketika saluran dalam keadaan matched sempurna.

c. $\Gamma=+1$ : refleksi positif maksimum, ketika saluran dalam rangkaian terbuka.

Rumus untuk mencari nilai VSWR seperti persamaan 8 dibawah ini [10]:

$S=\frac{\left.V\right|_{m a k}}{V_{m g} m}=\frac{\hbar+r}{ \pm-r}$

Keterangan :

$\mathrm{S} \quad=\mathrm{VSWR}$

$|\mathrm{V}|_{\text {mak }}=$ Tegangan maksimum

$|\mathrm{V}|_{\min }=$ Tegangan minimum

$\Gamma \quad=$ Koefisien refleksi

Kondisi yang paling baik adalah ketika VSWR bernilai $1(S=1)$ yang berarti tidak ada refleksi ketika saluran dalam keadaan matching sempurna. Namun kondisi ini pada praktiknya sulit untuk didapatkan. Oleh karena itu, nilai standar VSWR yang diijinkan untuk pabrikasi antena adalah VSWR $\leq 2$.

\section{GSM}

Global System For Mobile Communication (GSM) merupakan teknologi yang dapat mentransmisikan voice, data namun rate-nya masih kecil

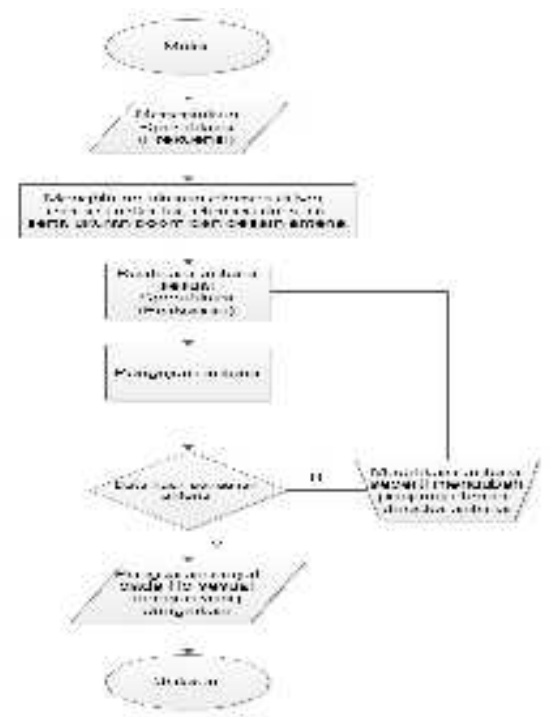


yaitu 9,6 kbps untuk data dan $13 \mathrm{kbps}$ untuk voice, menggunakan teknologi circuit switch, artinya pembagian kanal dimana setiap satu kanal itu mutlak dimiliki oleh satu user. Sistem komunikasi bergerak seluler GSM mempunyai spesifikasi yang telah ditetapkan oleh European Telecommunications Standard Institute (ETSI) seperti terlihat pada Tabel 1 dibawah ini :

Tabel 1. Spesifikasi Parameter Air Interface GSM

(Sumber : Konsep Teknologi Seluler hal. 29)

\begin{tabular}{c|c}
\hline Band Frekuensi & $\begin{array}{c}\text { Up Link 890-915 } \\
\text { MHz } \\
\text { Down Link 935- } \\
\mathbf{9 6 0 ~ M H z}\end{array}$ \\
\hline Duplex Spacing & $45 \mathrm{MHz}$ \\
Carrier Spacing & $200 \mathrm{KHz}$ \\
Modulasi & $\mathrm{GMSK}$ \\
Transmission Rate & $27 \mathrm{Kbit} / \mathrm{s}$ \\
Speech Coder & $13 \mathrm{Kbit} / \mathrm{s}$ \\
Time Slot per & 8 time slot \\
Frekuensi carrier & $4,615 \mathrm{~ms}$ \\
Periode Frame & $576,9 \mu \mathrm{s}$ \\
Periode Time Slot &
\end{tabular}

PERANCANGAN SISTEM

\section{Flowchart Rancang Bangun Antena} Yagi

Gambar 6. Flowchart rancang bangun antena yagi

Hal yang pertama agar dapat merealisasikan antena yagi yaitu menentukan spesifikasi frekuensi kerja antena dan bahan yang digunakan untuk antena yagi. Menghitung ukuran dan membuat desain yang diinginkan agar mendapat hasil yang maksimal. Kemudian mulai merakit antena yang telah dihitung secara matematis. Setelah itu mulai proses realisasi pembuatan antena dan lakukan pengujian, apakah antena yagi tersebut dapat menguatkan sinyal handphone?, jika tidak lakukan modifikasi antena seperti mengubah panjang elemen director dan memeriksa catuan elemen driven. Pada gambar 7 dibawah ini dapat dilihat bagian-bagian dari antena yagi yang akan dibuat.

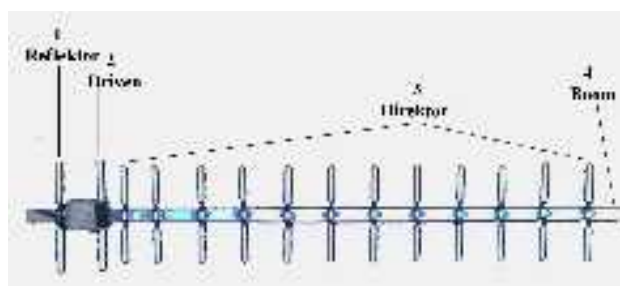

Gambar 7. Antena yagi yang dibuat dan nama tiap bagiannya

1. Mencari bahan dasar untuk antena

Bahan dasar yang digunakan dalam pembuatan antena sangat berpengaruh dengan kualitas sinyal yang diharapkan. Dan akan berpengaruh terhadap redaman serta pola radiasi antena tersebut. Ada beberapa bahan yang biasa digunakan untuk membuat antena misalnya tembaga dan alumunium. Penulis memilih alumunium sebagai bahan yang cocok dan baik untuk pembuatan antena yagi ini, dikarenakan faktor dielektrik yaitu faktor rambatan gelombang elektromagnetik terhadap bahan yang digunakan. Selain itu alumunium sangat ringan dan harganya lebih ekonomis dibandingkan dengan tembaga. Hal tersebut dapat dilihat pada table 2 dibawah ini.

Bahan yang banyak digunakan untuk saluran listrik adalah jenis tembaga, namun harga tembaga lebih mahal dan tidak stabil bahkan cenderung naik sehingga alumunium mulai dilirik dan dimanfaatkan sebagai bahan saluran listrik, baik saluran udara maupun saluran bawah tanah.

Jadi penulis menggunakan bahan alumunium berbentuk slinder dengan diameter $3 / 8$ inchi. Ukuran diameter ini adalah ukuran alumunium berbentuk slinder yang paling kecil agar antena yang dibuat lebih ringan. 
Tabel 2. Perbandingan Tembaga dan Alumunium

Sumber : Diakses dari digilib.petra.ac.id. Pada tanggal 15 desember 2012 pukul 21.30 wib

\begin{tabular}{|c|c|c|}
\hline Faktor & Tembaga & Alumunium \\
\hline Dielektrik & $\begin{array}{l}\text { Daya } \\
\text { hantar } \\
\text { listrik } \\
\text { sangat baik } \\
\text { dengan } \\
\text { konduktifit } \\
\text { as listrik } \\
6,0.10^{-7} \\
\Omega \mathrm{m}\end{array}$ & $\begin{array}{l}\text { Daya hantar } \\
\text { listrik } \\
\text { rendah } \\
\text { dengan } \\
\text { konduktifita } \\
\text { s listrik } \\
3,8.10^{-7} \Omega \mathrm{m}\end{array}$ \\
\hline Tahanan Jenis & $\begin{array}{l}1,7241.10^{-8} \\
\Omega \mathrm{m}\end{array}$ & $\begin{array}{l}2,8264.10^{-8} \\
\Omega \mathrm{m}\end{array}$ \\
\hline Permeabilitas & 0,999991 & 1,00002 \\
\hline Material & $\begin{array}{l}\text { Relative } \\
\text { berat (berat } \\
\text { jenis }=8,9 \\
\mathrm{gr} / \mathrm{cm}^{3} \text { ) }\end{array}$ & $\begin{array}{l}\text { Lebih ringan } \\
\text { (berat jenis } \\
=2,7 \\
\mathrm{gr} / \mathrm{cm}^{3} \text { ) }\end{array}$ \\
\hline Harga & $\begin{array}{l}\text { Relative } \\
\text { lebih } \\
\text { mahal }\end{array}$ & $\begin{array}{l}\text { Kompetitif/ } \\
\text { lebih murah }\end{array}$ \\
\hline
\end{tabular}

2. Pengujian antena

Pada tahap pengujian antena dilakukan pengujian antena di dalam labor

dan di luar gedung, sehingga penulis dapat melihat apakah antena tersebut sudah bekerja dengan baik.

Pengukuran didalam labor yaitu pengukuran menggunakan pemancar RF generator dengan nilai amplitudo maksimal pada RF generator sebesar + 16,5 $\mathrm{dBm}$ dan dihubungkan dengan antena folded sebagai antena pemancar. Antena penerimanya adalah antena yagi yang dihubungkan dengan spectrum analyzer untuk mengetahui daya yang diterima oleh antena yagi.
Pengukuran di luar gedung yaitu pengukuran menggunakan BTS sebagai pemancar. Untuk antena penerimanya sama dengan antena penerima pada pengukuran didalam labor yaitu menggunakan antena yagi yang terhubung dengan spectrum analyzer.

Untuk itu pengukuran harus dilakukan dengan teliti dan secermat mungkin agar hasil rancangan antena yagi sesuai dengan apa yang diinginkan.

\section{Flowchart Pengukuran antena Yagi 14 Elemen}

Flowchart pengukuran dengan pemancar antena folded (Indoor)

Gambar 8. Flowchart pengukuran antena yagi 14 elemen dengan pemancar antena folded (Indoor)

Flowchart pengukuran dengan pemancar BTS (Outdoor)

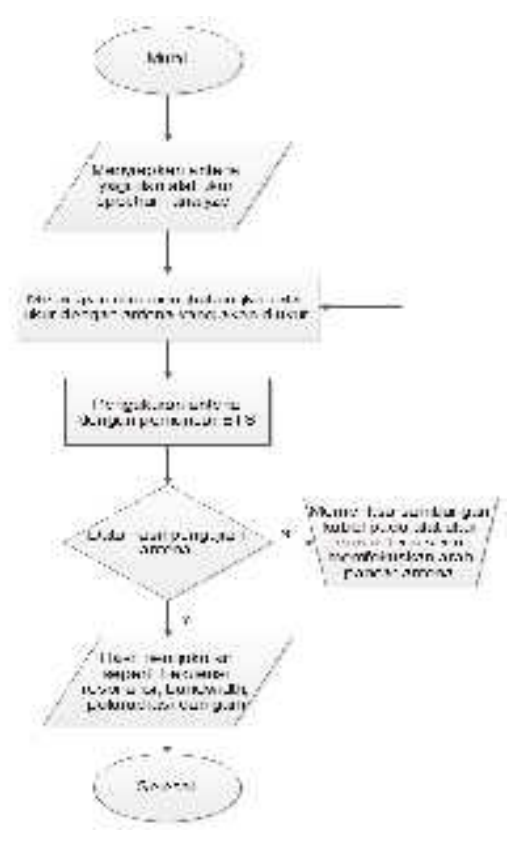


Gambar 9. Flowchart pengukuran antena yagi 14 elemen dengan pemancar BTS (Outdoor)

Untuk melakukan pengukuran antena yagi 14 elemen pertama-tama menyiapkan alat yang diperlukan pada pengukuran di dalam labor (indoor) seperti RF generator sebagai pembangkit tegangan, antena folded sebagai antena pemancar, antena penerima yaitu antena yagi 14 elemen dan spectrum analyzer sebagai alat ukur daya yang diterima oleh antena penerima. Sedangkan untuk pengukuran dengan pemancar BTS (outdoor), tidak perlu menggunakan RF generator dan antena folded karena BTS telah berfungsi sebagai pemancar sinyal.

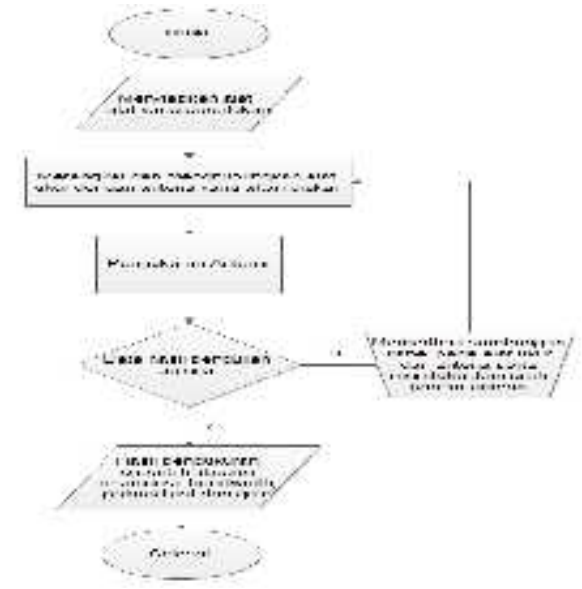

Hubungkan antena folded dengan RF generator dan disisi penerima hubungkan antena yagi dengan spectrum analyzer, penghubungan menggunakan kabel RG58 dengan impedansi $50 \Omega$. Setelah itu mulailah untuk mengukur antena dengan cara memberi tegangan pada RF generator dan lihat daya terima antena yagi pada spectrum analyzer. Jika daya terima belum maksimum, coba periksa sambungan kabel dan memfokuskan arah pancar antara antena pemancar dengan antena penerima.

Pengukuran yang dilakukan akan menghasilkan frekuensi resonansi, bandwidth, polaradiasi dan gain antena yang diukur.

\section{HASIL DAN PEMBAHASAN}

\section{Analisa Penentuan Frekuensi Resonansi}

Penentuan frekuensi resonansi adalah langkah awal dalam pengukuran antena. Hasil dari penentuan frekuensi resonansi ini digunakan untuk melihat frekuensi kerja antena yang dirancang sesuai atau tidaknya dengan pengukuran yang dilakukan. Pengukuran yang dilakukan menggunakan dua pemancar dan lokasi yang berbeda yaitu menggunakan antena folded di ruangan labor dan menggunakan BTS di rungan terbuka.

Hasil pengukuran untuk menentukan frekuensi resonansi dapat dilihat pada grafik dibawah ini.

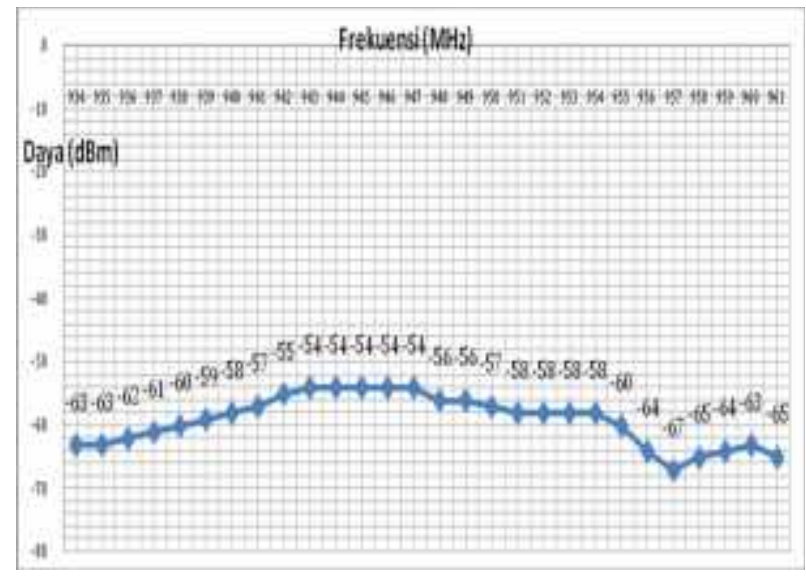

Gambar 10. Grafik frekuensi antena Yagi 14 elemen dengan pemancar antena Folded

Setelah melakukan pengukuran daya terima antena yagi 14 elemen dengan antena folded sebagai antena pemancar dan melihat grafik frekuensi pada gambar 4.5, didapatkan daya maksimumnya bernilai $-54 \mathrm{dBm}$ pada frekuensi 943-947 MHz. 


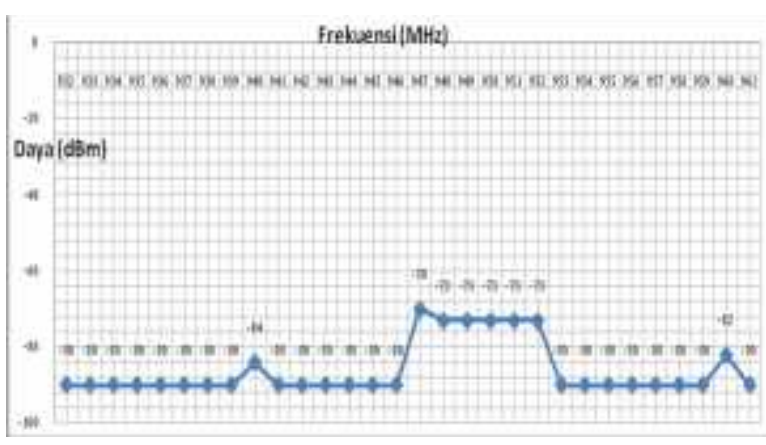

Gambar 11. Grafik frekuensi antena Yagi 14 elemen dengan pemancar BTS

Setelah melakukan pengukuran daya terima antena yagi 14 elemen dengan antena folded sebagai antena pemancar dan melihat grafik frekuensi pada gambar 4.6, didapatkan daya maksimumnya bernilai $-70 \mathrm{dBm}$ pada frekuensi $947 \mathrm{MHz}$.

Hal tersebut membuktikan bahwa hasil yang didapatkan secara teori dengan praktek sama yaitu frekuensi resonansi terdapat pada frekuensi 947 MHz. Hal ini bisa terjadi karena faktor pemilihan kabel koaxial, ukuran panjang elemen serta jarak elemen yang digunakan dalam pembuatan antena. Sehingga hasil teori dan prakteknya sama.

\section{Diagram Polaradiasi Antena Yagi 14 Elemen}

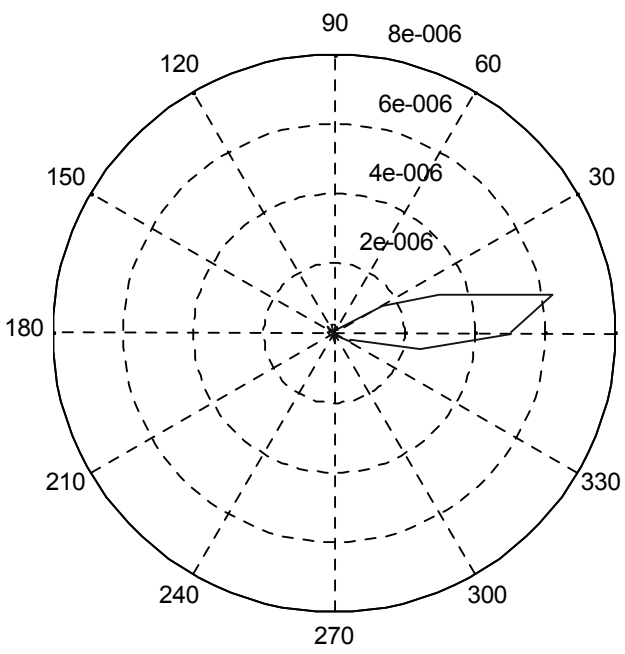

Gambar 12. Polaradiasi antena yagi 14 elemen dengan pemancar antena folded

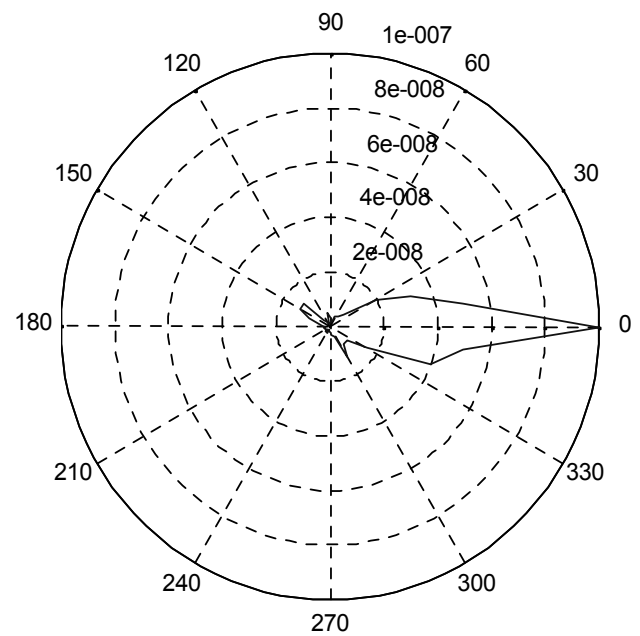

Gambar 13. Polaradiasi antena yagi 14 elemen dengan pemancar BTS

\section{Hasil Pegukuran Indoor dan Outdoor}

a. Pemancar dengan antena folded, dan sebagai antena penerima adalah antena dipole $1 / 2 \lambda$ dan antena yagi.

Tabel 4.3 Hasil pengukuran daya dengan antena pemancar folded (indoor)

\begin{tabular}{c|c|c|c}
\hline $\begin{array}{c}\text { Frekuensi } \\
(\mathrm{MHz})\end{array}$ & $\begin{array}{c}\text { Daya } \\
\text { Pemancar } \\
\text { Folded } \\
(\mathrm{dBm})\end{array}$ & $\begin{array}{c}\text { Daya } \\
\text { Penerima } \\
\text { dipole } 1 / 2 \\
\lambda(\mathrm{dBm})\end{array}$ & $\begin{array}{c}\text { Daya } \\
\text { Penerima } \\
\text { Yagi 14 } \\
\text { elemen(dBm) }\end{array}$ \\
\hline 947 & $+16,5$ & -68 & -52 \\
\hline
\end{tabular}

b. Pemancar dengan BTS, dan sebagai antena penerima adalah antena dipole dan antena yagi

Tabel 4.4 Hasil pengukuran daya dengan pemancar BTS (outdoor)

\begin{tabular}{c|c|c}
\hline $\begin{array}{c}\text { Frekuensi } \\
(\mathrm{MHz})\end{array}$ & $\begin{array}{c}\text { Daya } \\
\text { Penerima } \\
\text { dipole(dBm) }\end{array}$ & $\begin{array}{c}\text { Daya Penerima } \\
\text { Yagi 14 } \\
\text { elemen(dBm) }\end{array}$ \\
\hline 947 & -82 & -70 \\
\hline
\end{tabular}




\section{Pengaruh Penggunaan Antena Yagi Terhadap Kualitas Sinyal Handphone GSM}

Pada dasarnya penerimaan sinyal GSM cukup bagus, hanya saja berlaku pada titik-titik tertentu yang dekat dengan BTS GSM. Sedangkan wilayah yang berada lebih jauh dari BTS kurang maksimal memperoleh sinyal GSM. Selain itu lokasi penggunaan handphone GSM yang berada pada daerah yang berbukit-bukit dan bangunan-bangunan tinggi penerimaan sinyalnya kurang bagus.

Hal yang paling sering dilihat dari user dalam menggunakan jaringan telekomunikasi adalah sinyal bar pada handsetnya, yang merepresentasikan signal strength atau kekuatan sinyal. Kekuatan sinyal atau level sinyal ini diukur dengan satuan $\mathrm{dBm}$ atau desible dalam milliwatt.

Akan tetapi pengukuran daya terima sinyal handphone tanpa menggunakan antena yagi ini tidak terbaca oleh spectrum analyzer sehingga perhitungan daya terima handphone menggunakan referensi dari jurnal Pola dan Model Keruangan Kualitas Penerimaan Sinyal Telepon Seluler di Kota Bukittinggi yang dibuat oleh Sobirin, Adi Wibowo dan Alhamdi Yosef Herman, seperti dijelaskan pada Tabel 5 berikut ini.

Tabel 5. Tingkat kuat sinyal telepon seluler

Sumber : Jurnal Pola dan Model

Keruangan Kualitas Penerimaan

Sinyal Telepon Seluler di Kota Bukittinggi, diakses dari http://geografi.ui.ac.id/portal/sivitasgeografi/dosen/makalahseminar/pola-dan-model-keruangankualitas-penerimaan-sinyal-telepon- seluler-di-kota-bukittinggi. Pada tanggal 19 des 2012 pukul 15.00 wib.

\begin{tabular}{c|c|c}
\hline $\begin{array}{c}\text { Tingkat Kuat } \\
\text { Sinyal (bar sinyal ) }\end{array}$ & Kategori & $\begin{array}{c}\text { Nilai Kuat } \\
\text { Sinyal (dBm) }\end{array}$ \\
\hline $\mathbf{5 / F u l l ~}$ & $\begin{array}{c}\text { Sangat } \\
\text { baik }\end{array}$ & $>\mathbf{- 6 0}$ \\
4 & Baik & $\mathbf{- 6 0}$ s/d $\mathbf{- 7 0}$ \\
$\mathbf{3}$ & Cukup & $\mathbf{- 7 1} \mathbf{s} / \mathbf{d} \mathbf{- 8 0}$ \\
2 & Buruk & $\mathbf{- 8 1} \mathbf{~ s / d ~ - 9 0}$ \\
$>1$ & Sangat & $<-90$ \\
\multicolumn{2}{|c}{ Dari tabel 5 diatas dapat di }
\end{tabular}

jelaskan tingkat kuat sinyal handphone yang akan di aplikasikan pada antena yagi maupun menngunakan antena standart (tanpa menggunakan antenna yagi). Handphone GSM yang digunakan adalah samsung GT-E1080F dengan provider indosat. Indosat adalah salah satu provider yang masih menggunakan GSM900 dan sinyalnya sangat lemah di area kampus Politeknik Negeri Padang. Sebelum menggunakan antena yagi atau sewaktu menggunakan antena standart yang ada pada handphone GSM, sinyal yang diperoleh tidak ada. Perbandingan daya terima dengan handphone dengan antena standart maupun dengan antena yagi tersebut dapat dilihat pada table 6 berikut ini.

Tabel 6. Perbandingan daya terima yang diasumsikan

\begin{tabular}{|c|c|c|}
\hline Handphone & $\begin{array}{c}\text { dBm } \\
\text { Range }\end{array}$ & Keterangan \\
\hline $\begin{array}{l}\text { Dengan antena } \\
\text { standar }\end{array}$ & $>-90$ & $\begin{array}{c}\text { Tidak ada } \\
\text { sinyal }\end{array}$ \\
\hline Dengan yagi & -70 & Baik \\
\hline
\end{tabular}

Daya terima maksimal antena yagi 14 elemen dengan pemancar BTS sebesar -70 dBm. Kemudian setelah menghubungkan antena yagi dengan handphone, sinyal pada hanphone muncul bahkan dapat tampil pada layar handphone sampai 4 bar. Tampilan kenaikan sinyal bar pada handphone 
dapat dilihat pada lampiran 2. Hal tersebut membuktikan bahwa antena yagi dapat menguatkan sinyal pada handphone.

\section{KESIMPULAN}

Berdasarkan hasil penelitian, dapat diperoleh beberapa kesimpulan yaitu:

Pada pengukuran gain antena, nilai gain antena yagi dengan pemancar antena folded sebesar $16 \mathrm{~dB}$, sedangkan dengan pemancar BTS gain antena yagi sebesar 12 dB. Hasil pengukuran dengan pemancar antena folded lebih besar dari pada menggunakan pemancar BTS. Hal ini disebabkan karena pada pengukuran jarak antara antena pemancar dengan antena penerima berbeda. Sehingga sangat mempengaruhi daya terima dari antena yagi itu sendiri.

\section{SARAN}

1. Pada saat perancangan lebih baik menggunakan software (perangkat lunak) antena yagi seperti Yagi Calculator, MMANAGAL dan yang lainnya agar mendapatkan ketelitian yang lebih baik dalam menentukan panjang dari elemenelemen antena yang dirancang.

2. Pada saat melakukan pengujian perhatikan kabel dan konektor yang digunakan. Pemasangan konektor pada kabel harus benar-benar terpasang dan rapi agar daya yang diterima maksimal. Dan pembuatan konektor handphone yang lebih cocok selain menggunakan Jack Audio.

\section{DAFTAR PUSTAKA}

[1] Robert E Kenward. 2001. A manual for widlife radio tangging, London: Acdemic Press, hal.31
[2] Siagian Mangasih. Antena BTS. diakses dari http://www.scribd.com/doc/9683367 4/Antenna-BTS, Pada tanggal 2 agustus 2012 pukul $01.00 \mathrm{wib}$

[3] Alaydrus Mudrik. 2011. Prinsip dan Aplikasi Antena, Edisi Pertama, Jakarta : Graha ilmu

[4] Wibisono Gunawan dkk. 2008 Konsep dasar teknologi seluler, Bandung: informatika, hal.150-151

[5] Reithofer Sepp. 1997. Merakit Sendiri Antena Gelombang Mikro 1$75 \mathrm{GHz}$ Termasuk Antena Parabola, Jakarta: PT Elek Media Komputindo, hal. 24

[6] Lesmana Y R. Jurnal Antena Yagi 2 $m$ Band. diakses dari http://antenausbmodem.blogspot.com/, Pada tanggal 1 agustus 2012 pukul 22.03 wib

[7] Rhodie, Cara Membuat Pigtail Modem Cdma/Gsm. diakses dari http://students amikom.blogspot.com/2011/11/cara -membuat-pigtail-modemcdma/gsm, Pada tanggal 24 september 2012 pukul 14:40 wib.

[8] Jurnal Pola dan Model Keruangan Kualitas Penerimaan Sinyal Telepon Seluler di Kota Bukittinggi, diakses dari

http://geografi.ui.ac.id/portal/sivitasgeografi/dosen/makalahseminar/pola-dan-model-keruangankualitas-penerimaan-sinyal-teleponseluler-di-kota-bukittinggi. Pada tanggal 19 desember 2012 pukul 15.00 wib. 
ISSN :2085-6989 